
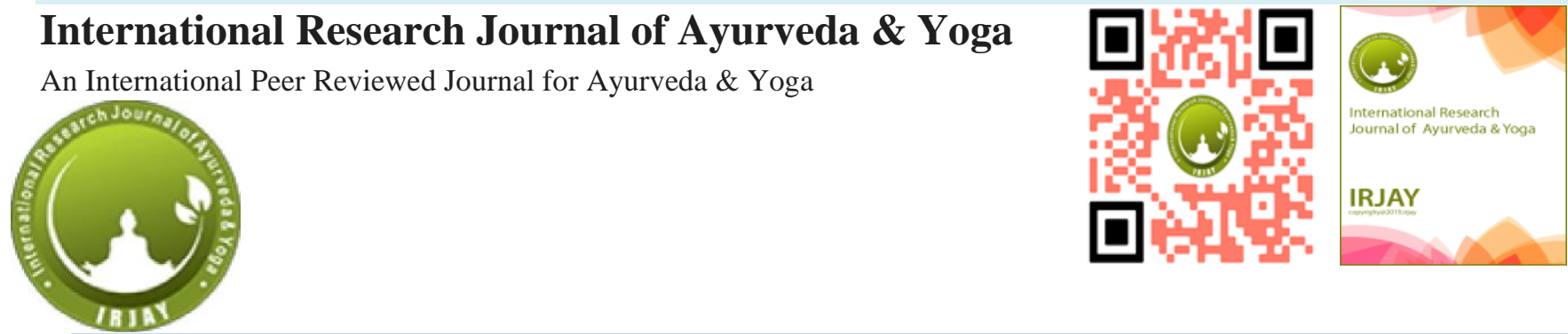

\title{
A Conceptual Study To Evaluate The Effect Of Virechana Karma, Raktamokshan, And Shaman Aushadha In The Management Of Ekakushtha w.s.r To Psoriasis
}

\author{
Dr.Himanshu Sharma ${ }^{1}$, Prof.Pushpinder Singh ${ }^{2}$, Dr.Rajesh Kumar Sood ${ }^{3}$
}

ICV-70.44- ISRA-1.318

VOLUME 4 ISSUE 5

1. PG scholar, PG department of Panchkarma, R.G.G.P.G.Ayurvedic College Paprola Distt. Kangra H.P India.

2. Professor \&HOD PG Dept. of Panchkarma, R.G.G.P.G.Ayurvedic College Paprola, Distt. Kangra H.P India.

3. HOD PG Dept. of Samhita \& Siddhanta, I/C of Skin Care Unit \& Derma Research lab R.G.G.P.G.Ayurvedic College Paprola, Distt. Kangra H.P India.

Corresponding Author:- Dr.Himanshu Sharma PG scholar, PG department of Panchkarma, R.G.G.P.G.Ayurvedic College Paprola Distt. Kangra H.P India.

\begin{abstract}
: -
Introduction-In Ayurveda all the skin diseases has been discussed under the broad term "Kushtha". It can be classified into Mahakushtha (major skin diseases) and Kshudrakushtha (minor skin diseases). Ekakushtha is one among the Kshudra Kushtha presenting clinical features - Aswedanam (loss of sweating), Mahavastu (larger area of involvement), Matsya Shaklopamam (scaling) ${ }^{l}$. Ekakushtha can be correlated with psoriasis on the basis of similarity in etiopathogenesis \& symptomatology. Psoriasis is a chronic autoimmune, frequently recurring disease that vary in severity from the merely annoying to life threatening. Although no treatment can completely cure this disease. Acharya has highlighted the role of Panchkarma therapy by stating that the disease treated by Shodhan (Purification treatment) will never recur whereas the treatment with shaman therapy may recur in due course of time. This research work was conducted with the aim to establish an effective therapy under Panchkarma Chikitsa for the management of disease.

Method: In this trial 10 patients of Ekakushtha (Psoriasis) were selected from the O.P.D of Panchkarma Dept. RGGPGAC Ayurvedic college \& hospital, Paprola, Distt-Kangra H.P. Virechana, Raktmokshana followed by Shaman Aushadha were chosen for the study.

Results: The therapy used in this clinical study were found significantly effective in all symptoms of the disease, which were taken for the study.

Discussion: Ekakushtha (Psoriasis) is a Kshudrakustha (minor skin diseases), which have Vata Kapha Dosha dominancy. Single dosha cannot cause Kushtha (skin diseases), we can say it is a Tridoshaja Vyadhi. Acharya indicates Shodhana Chikitsa (Purification) in Bahu Doshaja state of Kustha ${ }^{2}$. As per our observation, Virechana (Purgation) and Raktmokshana (bloodletting) followed by Shaman Aushadha (Pacification treatment) are best line of treatment in Ekakushtha (Psoriasis).
\end{abstract}

Key words: Ekakushtha, Psoriasis, Panchkarma, Virechana, Raktmokshan, Samshodhana. 
This work is licensed under a creative attribution -Non-commercial-No derivatives 4.0 International License commons

How to cite this article: Dr.Himanshu Sharma, Prof. Pushpinder Singh, Dr.Rajesh Kumar Sood "A Conceptual Study To Evaluate The Effect Of Virechana Karma, Raktamokshan, And Shaman Aushadha In The Management Of Ekakushtha W.S.R To Psoriasis"IRJAY, May: 2021, Vol-4, Issue5;36-44 ; DOI: https://doi.org/10.47223/IRJAY.2021.4501

\section{INTRODUCTION:}

In present scenario, continuous changing life styles, environment and dietary habits have made man as main victim of many diseases including skin diseases.

All the skin diseases in Ayurveda have been discussed under the broad heading "Kushtha", which are further divided in to Mahakushtha (major skin diseases) and Kshudrakushtha (minor skin diseases).

All Acharyas have described that all Kushtha (skin diseases) have Tridoshika involvement. Ekakushtha (Psoriasis) is one among the Kshudrakushtha (minor skin diseases).which has dominance of Kapha \& Vata Dosha in particular and Rakta (blood) in general which is main cause for its pathogenesis. Ekakustha (Psoriasis) can be correlated with psoriasis on the basis of similarity in etiopathogenesis \& symptomatology. Symptoms as per Ayurvedic aspect of Ekakushtha are Aswedanam, Mahavastum, Matasyashklopamam, Karishana Aruna Varana can be correlated to anhidrosis, extent of lesion, scaling, erythema of psoriasis respectively. Psoriasis is a chronic autoimmune condition, characterized by an exaggerated proliferation of keratinocytes secondary to an activated immune system.

The autoimmune diseases are mysterious set of conditions that vary in severity and has negative impact on quality of life, requires long term treatment, which usually has a high social and economic impact and is also associated with a decreased life span. The unique treatment modality of Ayurveda provides long lasting results and a better life to patients through its three basic principles of treatment i.e. - Shodhana (Purification), Shamana
(Pacification)and Nidana Parivarjana (Avoidance of causative factor) ${ }^{3}$.

All Acharyas mentioned that Kushtha (Skin diseases) is Raktaj vayadhi. In Kushta Rakta Dhatu (Blood) which is responsible for Prasara (Stage of Spreading) stage of Kushta Samprapti (Pathogenesis) Pitta Dosha and Rakta Dhatu have Ashraya-Ashrayi Relationship (Between Tissues And Doshas) relationship hence treatment modality of Pitta Dosha and Rakta Dhatu complimenting to each other.

Therefore for the eliminations of vitiated Pitta Dosha Virechana (purgation) and Raktmokshana (bloodletting) ${ }^{4}$ followed with Shamana Aushadha (pacification) can play significant role in management of Ekakushtha (psoriasis).

\section{AIMS AND OBJECTIVES}

1. To assess the efficacy of Virechan Karma (purgation) in Ekakushtha.

2. To assess the efficacy of Rakatmokshan (bloodletting) in Ekakushtha.

3. To develop effective Ayurvedic treatment for Ekakushtha.

\section{MATERIAL AND METHODS}

Patients with classical signs \& symptoms of the Ekakushtha, according to Ayurvedic classics as well as modern science were selected from the O.P.D. \& I.P.D. of R.G.G.P.G.Ayu.College \& Hospital, Paprola (Kangra) H.P. 10 patients who fulfilled the inclusion criteria of diagnosis were selected. All patients completed the trial. Duration of study - 30 days 
IEC Number: Ayu/IEC/2017/1161

\section{SELECTION OF PATIENTS: Inclusion Criteria}

1. Patient willing for clinical study.

2. Age group $20-70$ years irrespective of sex, education, religion, socioeconomic status etc.

3. Patient showing signs and symptoms of Ekakushtha and "Psoriasis".

\section{Exclusion Criteria}

1. Patients not willing for the study.

2. Patients below 20 and above 70 years.

3. Patients suffering from peptic ulcers, cardiac disease and any infectious diseases were not included in the study.

4. Malignancy.

5. Patients already taking chemotherapy, radiotherapy.

6. Pregnant and lactating women.

7. Allergy to the research drugs.

PLAN OF STUDY: Study was carried out in single group of 10 patients with treatment schedule as follow -

Table 1- Grading for Assessment Aswedanam (Anhidrosis)

\begin{tabular}{|l|l|l|l|}
\hline Symptom & N.S. & B.T. & A.T. \\
\hline Normal Sweating & 0 & & \\
\hline Mild Sweating & 1 & & \\
\hline Mild Sweating after exercise & 2 & & \\
\hline No Sweating after exercise & 3 & & \\
\hline No Sweating & 4 & & \\
\hline
\end{tabular}

\section{Mahavastum (Extent of lesion)}

\begin{tabular}{|l|l|l|l|}
\hline Symptom & N.S. & B.T. & A.T. \\
\hline No Lesions on body & 0 & & \\
\hline Lesions on elbow, knee, lumbosacral, scalp & 1 & & \\
\hline Lesions on forearm, leg, neck, scalp, trunk, back & 2 & & \\
\hline Lesions on most parts of body & 3 & & \\
\hline Lesions on whole body & 4 & & \\
\hline
\end{tabular}

1. Snehpana (Abhyantra Snehana) -

Darvi Ghrita ${ }^{5-}$ Dose starting from $30-50 \mathrm{ml}$ as per Koshta and Agni of the patient in increasing dose till the appearance of Samayak Snehana Lakshana.

2. Sarvang Abhayanga

Sarshpa tail-As per requirement of the Sarvang Abhyanga for three days (Ch.Chi 7/119)

Swedana - Nadi Swedana ( Mridu )

3. Virechan Karma-

Virechana yoga ${ }^{6}$ - Trivrit $-5-10 \mathrm{gm}$

Triphala - 50-100ml

Followed by Samsarjana Krama as mentioned in Shodhana process.

4. Raktmokshan-Siravedha

Snehpana-Darvi Ghrita for 3 days. On the $9^{\text {th }}$ day of Virechana Karma.

Siravedha -Siravedha done after Snehan, Swedan and Yavagu Pana.

Followed by local application of Karveer Mool Lepa ${ }^{7}$ on affected areas and Argvadh Patra Kwatha ${ }^{8} 20 \mathrm{ml}$ BD for 10 days. 


\section{Matsyashaklopamam (Scaling)}

\begin{tabular}{|l|l|l|l|}
\hline Symptom & N.S. & B.T. & A.T. \\
\hline No Scaling & 0 & & \\
\hline Mild scaling by rubbing or itching from lesion & 1 & & \\
\hline Moderate scaling by rubbing or itching from lesion & 2 & & \\
\hline Severe scaling by rubbing or itching from lesion & 3 & & \\
\hline Severe scaling without itching & 4 & & \\
\hline
\end{tabular}

\section{Krishna Aruna Varna (Erythema)}

\begin{tabular}{|l|l|l|l|}
\hline Symptom & N.S. & B.T. & A.T. \\
\hline Normal color & 0 & & \\
\hline Faint or near to normal & 1 & & \\
\hline Light reddish color & 2 & & \\
\hline Moderate red color & 3 & & \\
\hline Bright red color & 4 & & \\
\hline
\end{tabular}

\section{Kandu (Itching)}

\begin{tabular}{|l|l|l|l|}
\hline Symptom & N.S. & B.T. & A.T. \\
\hline No Itching & 0 & & \\
\hline Mild/Occasional Itching & 1 & & \\
\hline Moderate(tolerable)Infrequent & 2 & & \\
\hline Severe Itching Frequently & 3 & & \\
\hline Very severe Itching Disturbing & 4 & & \\
\hline
\end{tabular}

\section{Candle Grease sign:}

\begin{tabular}{|l|l|l|l|}
\hline Sign & N.S. & B.T. & A.T. \\
\hline Absent & 0 & & \\
\hline Present & 1 & & \\
\hline
\end{tabular}

\section{Auspitz's sign}

\begin{tabular}{|l|l|l|l|}
\hline Sign & N.S. & B.T. & A.T. \\
\hline Absent & 0 & & \\
\hline Present & 1 & & \\
\hline
\end{tabular}

\section{Koebner phenomena}

\begin{tabular}{|l|l|l|l|}
\hline Sign & N.S. & B.T. & A.T. \\
\hline Absent & 0 & & \\
\hline Present & 1 & & \\
\hline
\end{tabular}

\section{Psoriasis Area and Severity Index (PASI)}

It combines the assessment of the severity of lesions and the area affected in to a single score.

\section{Calculation}

Area of Involvement- The body is divided in to four sections -Head (10\% of a person's skin), arms (20\%), trunk (30\%) and legs (40\%). Each of these areas is scored and then four scores are combined in to final PASI score.

Within each area the severity is estimated by three clinical signs: Erythema, induration and desquamation. 


\section{OBSERVATION \& RESULTS:}

Table 2- Cardinal symptoms wise distribution of Ekakushtha of 10 patients :

\begin{tabular}{|l|l|l|}
\hline Cardinal symptoms & No. of Patients & $\%$ age \\
\hline Kandu & 10 & 100 \\
\hline Mahavastum & 10 & 100 \\
\hline Matsyashakalopamam & 10 & 100 \\
\hline Krishna Aruna Varna & 08 & 80 \\
\hline Asvedanama & 09 & 90 \\
\hline
\end{tabular}

Table 3-Signs of Psoriasis Wise Distribution:

\begin{tabular}{|l|l|l|}
\hline Signs of Psoriasis & No. of Patients & \%age \\
\hline Candle Grease sign & 9 & 90 \\
\hline Auspitz's sign & 9 & 90 \\
\hline Koebner's phenomenon & 8 & 80 \\
\hline
\end{tabular}

Table 4-Effect of therapy on Subjective Criteria:

\begin{tabular}{|l|l|l|l|l|l|l|l|l|l|}
\hline \multirow{2}{*}{ Parameters } & $\mathrm{N}$ & \multicolumn{2}{|c|}{ Mean } & D & $\begin{array}{l}\text { \%age } \\
\text { Relief }\end{array}$ & SD \pm & SE \pm & $\mathrm{T}$ & $\mathrm{P}$ \\
\cline { 3 - 11 } & & $\mathrm{BT}$ & $\mathrm{AT}$ & & & & & \\
\hline Kandu & 10 & 3.8 & 0.9 & 2.9 & 76.3 & 0.87 & 0.27 & 10.4 & $<0.001$ \\
\hline Mahavastum & 10 & 3.4 & 1.4 & 2.0 & 58.82 & 1.52 & 0.48 & 4.35 & $<0.05$ \\
\hline Matsyashak-lopamam & 10 & 3.0 & 0.5 & 2.5 & 83.3 & 0.85 & 0.26 & 9.30 & $<0.001$ \\
\hline Krishna Aruna Varna & 08 & 2.3 & 0.5 & 1.8 & 78.26 & 0.88 & 0.31 & 7.18 & $<0.001$ \\
\hline Aswedanam & 09 & 3.6 & 0.9 & 2.7 & 75 & 1.02 & 0.33 & 9.00 & $<0.001$ \\
\hline
\end{tabular}

Table 5-Effect of therapy on Objective Criteria:

\begin{tabular}{|c|c|c|c|c|c|c|c|c|c|}
\hline \multirow[t]{2}{*}{ Parameters } & \multirow[t]{2}{*}{$\mathrm{N}$} & \multicolumn{2}{|c|}{ Mean } & \multirow[t]{2}{*}{$\mathrm{D}$} & \multirow{2}{*}{$\begin{array}{l}\text { \%age } \\
\text { Relief }\end{array}$} & \multirow[t]{2}{*}{$\mathrm{SD} \pm$} & \multirow[t]{2}{*}{$\mathrm{SE} \pm$} & \multirow[t]{2}{*}{$\mathrm{T}$} & \multirow[t]{2}{*}{$\mathrm{P}$} \\
\hline & & BT & AT & & & & & & \\
\hline Candle Grease Sign & 09 & 0.9 & 0.1 & 0.8 & 88.8 & 0.3 & 0.11 & 8.00 & $<0.001$ \\
\hline Auspitz's Sign & 09 & 0.9 & 0.1 & 0.8 & 88.8 & 0.33 & 0.11 & 8.00 & $<0.001$ \\
\hline Koebner's Phenomenon & 08 & 0.8 & 0.1 & 0.7 & 87.5 & 0.35 & 0.12 & 7.00 & $<0.001$ \\
\hline PASI Score & 10 & 13 & 4.32 & 8.68 & 66.76 & 6.909 & 2.185 & 4.412 & $<0.001$ \\
\hline
\end{tabular}

\section{Effect of Therapy on Clinical Features}

* Kandu: The mean score of 3.8 came down to 0.9 after treatment. The reduction being 2.9 , showing $76.3 \%$ relief which is highly significant with $\mathrm{p}$ value $(\mathrm{p}<0.001)$.

* Mahavastum: The mean score of 3.4 came down to 1.4 after treatment. The reduction being 2.0 showing $58.82 \%$ relief which is significant with $\mathrm{p}$ value $(\mathrm{p}<0.05)$.

* Matsyashaklopamam: The mean score of 3.0 came down to 0.5 after treatment. The reduction being 2.5 showing $83.3 \%$ relief which is highly significant with $\mathrm{p}$ value $(\mathrm{p}<0.001)$.

* Krishna Aruna Varna: The mean score of 2.3 came down to 0.5 after treatment. The reduction being 1.8 showing $78.26 \%$ relief which is highly significant with $p$ value $(\mathrm{p}<0.001)$

Aswedanam: The mean score of 3.6 came down to 0.9 after treatment. The reduction being 2.7 showing $75 \%$ relief which is highly significant 
with $\mathrm{p}$ value $(\mathrm{p}<0.001)$

* Candle Grease Sign: The mean score of 0.9 came down to 0.1 after treatment. The reduction being 0.8 showing $88.8 \%$ relief which is highly significant with $\mathrm{p}$ value $(\mathrm{p}<0.001)$

* Au spitz's Sign: The mean score of 0.9 came down to 0.1 after treatment. The reduction being 0.8 showing $88.8 \%$ relief which is highly significant with $\mathrm{p}$ value $(\mathrm{p}<0.001)$
Koebnar's Phenomenon: The mean score of 0.8 came down to 0.1 after treatment. The reduction being 0.7 showing $87.5 \%$ relief which is highly significant with $\mathrm{p}$ value $(\mathrm{p}<0.001)$

PASI Score- The mean score of 13 came down to 4.32 after treatment. The reduction being 8.68 showing $66.76 \%$ relief which is highly significant with $\mathrm{p}$ value $(\mathrm{p}<0.001)$

\section{Figure no 1\& 2: Showing results before and after treatment}

\section{Before Treatment}

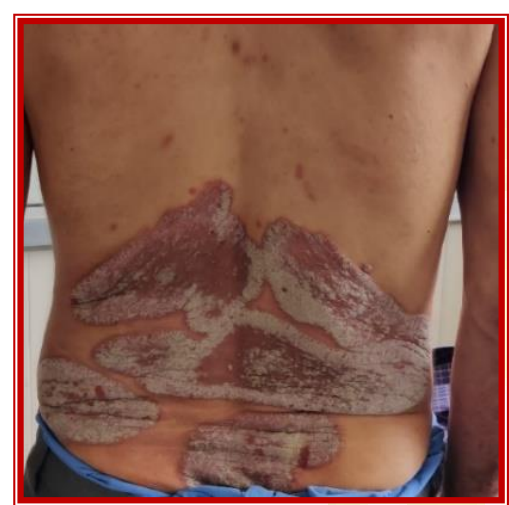

Figure 1.A

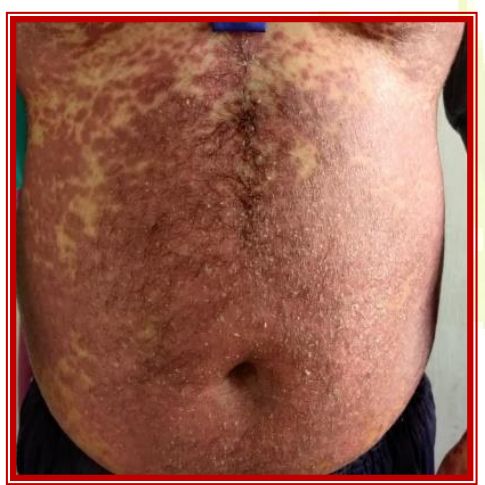

Figure1.B

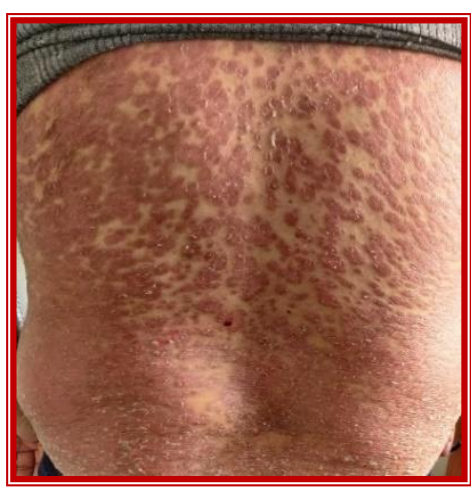

Figure 1.C

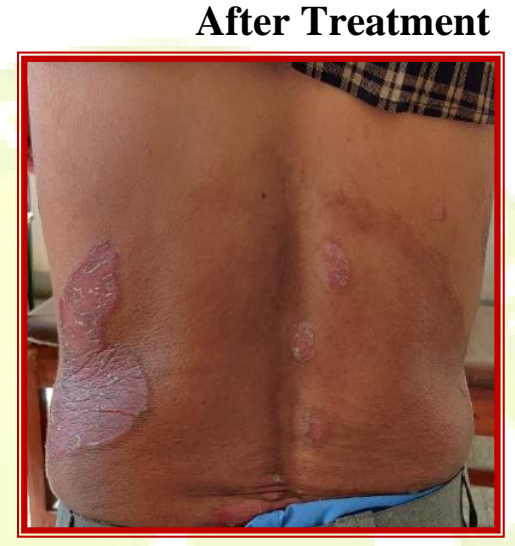

Figure 2.A

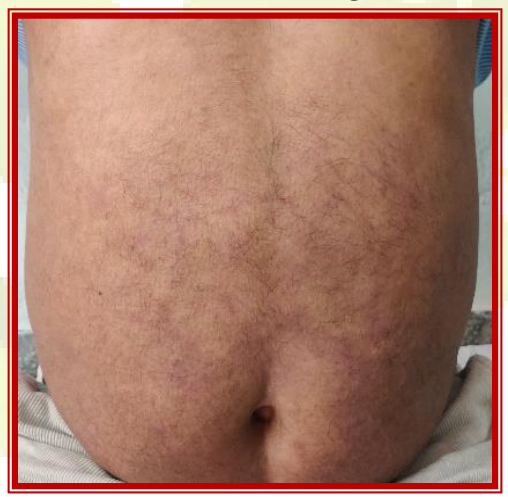

Figure 2. B

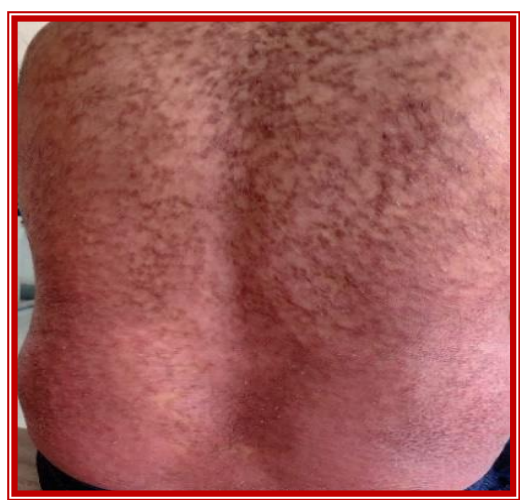

Figure 2.C 


\section{DISCUSSION:}

\section{Probable Mode Of Action}

Snehpana (internal oleation): Snehpana and Swedana (Sudation) has efficacy to remove Srotobandhana (blockage of channels) and liquify the morbid Dosha. In present study Darvi Ghrita was given for Abhyantra Snehana. Darvighrita reaches up to the cell due to its Ushna (hot), Laghu (light) and Sukshma Guna (sharp). And subsides the symptom like itching and scaling due to its Kanduhara (Antipruritic), Vranshodhan (wound cleaner) properties.

Berberine present in Daruharidra plays important role in the treatment of skin diseases due to its anti-inflammatory \& wound healing properties. It also has immunomodulatory and antioxidative effects.

\section{Virechana (Purgation) :}

Virechana yoga because of its Vyavayi Guna gets absorbed quickly by cell and tissue and due to its Virya (potency), it reaches to Hridya (heart), Dhammani (arteries) and all of the macro and micro channels of the body. Its Vikasi Guna (spreads all over the body) causes softening and loosening of the bond by Dhatu Shaithilya Karma. Ushna guna (hot) causes liquefications of Dosha Sanghata. It breaks the Mala (waste product) and Doshas in micro form due to its Tikshana Guna (sharp). Due to Sukshma Guna by reaching in micro channels, disintegrates endogenic toxins, which are then excreted through micro channels Virechana (purgation) occurs mainly due to Prabhava, Prithvi (earth)and Jala (water) constitution and presence of Sara Guna.

Regulation of Virechana process:

The process of Virechana (purgation) is regulated \& controlled by a special center situated near Medulla oblongata in the brain. When Virechana (purgation) drugs stimulate purgation center, indirectly vomiting center is relaxed. Sacral plexus of the spinal cord also helps in controlling \& regulating the act of purgation.

Virechana (purgation) is a Vyadhi pratyanika Chikitsa (disease specific treatment) Pitta is Mala of Rakta (blood). Virechana (purgation) expels Pitta, hence decreases Mala of rakta (Pitta) so ultimately it decreases the symptom of Kushtha (skin diseases). As we know that Ekakushtha is Vata kapha dominant disease with vitiation of Rakta Dosha (blood) \& psychosomatic nature of the disease.

Among the Panchkarma therapy by Virechana (purgation), Pitta Dosha clears not only from the Amashaya (stomach) but from all over the body i.e., from cellular level. Apart from Pitta it is also useful in disorders in which Pitta is associated with Vata or Kapha. ${ }^{9}$

Due to Vata Kaphaghna properties it reduces symptoms of Ekakushtha. Due to the Manaprasadana property it also reduces stress $\&$ stress related symptoms.

\section{Raktmokshana (Bloodletting):}

1. Raktmokshan (Bloodletting) comes under the Panchshudhi according to the Sushruta which means to purify the body from inside.

2. According to Acharya Charaka and Sushruta, Shodhana is necessary for disease due to Bahudosha Avastha (Multiple dosha). Ayurveda consider Rakta Dusti (blood) as one of the mainly due to Pitta Doshas. Siravedha (Bloodletting) removes vitiated Rakta thus Symptoms like Rukshta(dryness), Kandu(itching), Daha (burning sensation) and the extent of lesion will reduce after Siravedha karma (Bloodletting) due to Prabhut Dosha Niraharn by Siravedha and Rakta Shudhi.

3. Siravedha (Bloodletting) is effective to remove toxic materials so they can easily evacuate from body. Besides eliminating Pitta and Kapha Doshas, the main seat of Vata is also purified 
thereby making Siravedha Karma (Bloodletting) a Tridoshahara procedure.

4. Siravedha karma (Bloodletting) not only cleanses the body from inside but also does the Prasadan of the Mana (heart), Indriya (senses), Satva, Atma (soul) which are the tripod of life. It improves the quality life, life style, efficacy of life.

5. Psoriasis activated T cells migrates from lymph nodes and the blood stream into skin and release cytokines (INFy, IL-2) which induce pathological changes. Bloodletting therapy leads to reduction in IL-2,1. Hence it is effective in adjusting disorders of immune function like psoriasis.

6. As histamine are responsible for allergy, the symptoms like itching, patches diminish by bloodletting. Due to liberation of histamine through bloodletting.

7. HSP -70 (heat shock protein) has been proven to promote the survival rate of cells. Blood therapy leads to remarkable increase of local HSP70.

\section{Lepa:}

1. With topical application, the active principle of the Karveer Lepa reaches to the deeper tissues through Siramukha (opening of the vessels) \& Swedavahi Srotas (channels carrying sweat) ${ }^{10}$.

2. Due to its Ushna(hot), Tikshna(sharp), \& Sukshma properties it deblocks the obstruction in Swedavahisrotas \& allows the local toxins to flow out through the Sweda (Sweat), thus clearing out the micro channels.

3. Tikta Rasa (Astringent) has properties like Lekhana(emaciation), Deepana (appetizer), Pachana (digestive) by which it can remove obstruction (Sanga) of Kapha ${ }^{11}$.

In most of the patients Kandu (itching) was relieved significantly, this may be due to the Kandughna (anti-pruritic) property of Karveer mool.

\section{Kashyapana:}

Argvadha Patra Kashya is effective for reliving signs and symptoms of Ekakushtha and have Kushthghana, Kandughna (anti-pruritic), and Kapha Pitta Shamak properties.

\section{CONCLUSION:}

Ekakushtha (Psoriasis) can be successfully managed by repetitive Shodhana therapy (Purification) followed by specific Shamana Yoga (Antaha and Bahya). Symptoms like Kandu (Itching) and Matsyashaklopamam starts receding/relieved with Snehapana (Oleation). Virechana karma (Purgation) acts on all Doshas and is effective in treating Psoriasis. Virechana yoga (Purgation yogas) mentioned in Kushtha Chikitsa (skin diseases) in Charaka Samhita was proved as an effective drug for Virechana Karma \& has Kaphapittahara and Kushthahara action. Rakta dushti (vitiation of blood) is one of the prime causes of skin diseases. After letting out the vitiated Rakta (blood) it provides better relief in the symptoms.

In the present study maximum no. of patients $50 \%$ were moderately improved followed by $40 \%$ patients who showed marked improvement, followed by $10 \%$ patients with mild improvement.

On the basis of above findings, it can be concluded the Virechana Karma (purgation) Raktmokshana (bloodletting) followed by Shaman Aushadh (Pacification) is effective for the treatment of Ekakushtha (Psoriasis).

\section{Acknowledgment: Nil. \\ Financial Support: Nil. \\ Conflict of Interest: Nil}




\section{REFERENCES:}

1. Pt. Kashinath Shashtri and Dr. Gorakhnath Chaturvedi, Charak Samhita,Volume -2, Chikitsa Sathan chapter 7 versus 21, Published by Chaukhambha Sanskrit sansthan, Reprint 2014, pp-252

2. Pt. Kashinath Shashtri and Dr. Gorakhnath Chaturvedi, Charak Samhita, volume -2, Chikitsa Sathan Chapter 7 versus 31, Published by Chaukhambha Sanskrit sansthan, Reprint 2014, pp-253

3. Pt. Kashinath Shashtri and Dr. Gorakhnath Chaturvedi, Charak Samhita, volume -1, Vimana Sathan chapter 7 versus 30, Published by Chaukhambha Sanskrit sansthan, reprint 2014, pp-734

4. Pt. Kashinath Shashtri and Dr. Gorakhnath Chaturvedi, Charak Samhita, volume -2, Chikitsa Sathan Chapter 7 versus 39, Published by Chaukhambha Sanskrit sansthan, Reprint 2014, pp-255

5. Pt. Kashinath Shashtri and Dr. Gorakhnath Chaturvedi, Charak Samhita, volume -2, Chikitsa Sathan Chapter 7 versus 119, Published by Chaukhambha Sanskrit sansthan, Reprint 2014, pp-267

6. Pt. Kashinath Shashtri and Dr. Gorakhnath Chaturvedi, Charak Samhita, volume -2,
Chikitsa Sathan Chapter 7 versus 44, Published by Chaukhambha Sanskrit sansthan, Reprint 2014, pp-256

7. Pt. Kashinath Shashtri and Dr. Gorakhnath Chaturvedi, Charak Samhita, volume -2, Chikitsa Sathan Chapter 7 versus 94, Published by Chaukhambha Sanskrit sansthan, Reprint 2014, pp-264

8. Kumar, D. R., Sharma, D. A., Kumari, D. S., \& Gupta, D. A. (2021). Applied Aspect Of Shodhan Chikitsa In Psoriasis (Ekakustha): International Research Journal of Ayurveda \& Yoga, 4(3), 81-88.

9. Pt. Kashinath Shashtri and Dr. Gorakhnath Chaturvedi, Charak Samhita, volume -2, Chikitsa Sathan Chapter 7 versus 97-99, Published by Chaukhambha Sanskrit sansthan, Reprint 2014, pp-264

10. Dr. Anna Moreshwar Kunte and Pt. Krishna Ramchandra Shashtri Navre, Ashtang Haridya, Sarvanga Sundara and Ayurveda Rasayana commentaries, Sutra Sathan, Chapter 1 versus 25, Published by Chaukhamba Subharati Prakashan, Reprint 2013, pp- 25

11. Kaviraj Ambikadutta Shastri, Sushruta Samhita, volume-1, Sharir Sathan, chapter 9 versus 9, Published by Chaukhambha Sanskrit Sansthan, Varanasi, Reprint 2014, pp- 94 